\title{
TEMPERATURE EFFECT IN POTASSIUM AND NITRATE IONS IN SOIL TRANSPORT $^{1}$
}

\section{ADRIANO D. M. A. GONÇALVES ${ }^{2}$, JARBAS H. MIRANDA ${ }^{3}$, PAULO ROSSI ${ }^{4}$, JOSÉ F. G. SABADIN ${ }^{4}$, MARCOS Y. KAMOGAWA ${ }^{3}$}

\begin{abstract}
When doing researches on solute dynamics in porous medium, the knowledge of medium characteristics and percolating liquids, as well as of external factors is very important. An important external factor is temperature and, in this sense, our purpose was determining potassium and nitrate transport parameters for different values of temperature, in miscible displacement experiments. Evaluated parameters were retardation factor (R), diffusion/dispersion coefficient (D) and dispersivity, at ambient temperature $\left(25\right.$ up to $\left.28{ }^{\circ} \mathrm{C}\right), 40^{\circ} \mathrm{C}$ and $50{ }^{\circ} \mathrm{C}$. Salts used were potassium nitrate and potassium chlorate, prepared in a solution made up of $5 \mathrm{ppm}$ nitrate and $2.000 \mathrm{ppm}$ potassium, with Red-Yellow Latosol porous medium. Temperature exhibited a positive influence upon porous medium solution and upon dispersion coefficient.
\end{abstract}

KEYWORDS: breakthrough curves, miscible displacement, computational modeling.

\section{EFEITO DA TEMPERATURA NO TRANSPORTE DOS ÍONS POTÁSSIO E NITRATO NO SOLO}

RESUMO: No estudo da dinâmica de solutos num meio poroso, é de suma importância o conhecimento das propriedades do meio e dos líquidos percolantes, bem como de fatores externos. Um fator externo relevante é a temperatura e, nesse sentido, teve-se como objetivo determinar os parâmetros de transporte dos íons potássio e nitrato para diferentes valores de temperatura em experimentos de deslocamento miscível. Os parâmetros avaliados foram o fator de retardamento (R), o coeficiente de difusão/dispersão (D) e a dispersividade ( $\lambda$ ), e as temperaturas utilizadas foram a ambiente $\left(25\right.$ a $\left.28{ }^{\circ} \mathrm{C}\right), 40^{\circ} \mathrm{C}$ e $50^{\circ} \mathrm{C}$. Os sais utilizados foram nitrato de potássio e cloreto de potássio, preparados em solução composta de $50 \mathrm{ppm}$ de nitrato e $2.000 \mathrm{ppm}$ de potássio, sendo o meio poroso um Latossolo Vermelho-Amarelo, textura média. A temperatura apresentou influência positiva na velocidade da solução no meio poroso e no coeficiente de dispersão.

PALAVRAS-CHAVE: curvas de distribuição de efluentes, deslocamento miscível, modelagem computacional.

\footnotetext{
${ }^{1}$ Extracted from first author's Mastership Dissertation.

${ }^{2}$ M.Sc. in Agro-Environmental Physics, Department of Exact Sciences, ESALQ/USP, Av. Pádua Dias, 11, Piracicaba - SP, Brazil, admgonca@esalq.usp.br

${ }^{3}$ Prof. Dr., Department of Exact Sciences, ESALQ/USP, Piracicaba - SP, Brazil.

${ }^{4}$ Undergraduate Student of Agronomy Engineering, ESALQ/USP, Piracicaba - SP, Brazil.

Received by Editorial Board on February, 21, 2007

Approved by Editorial Board on June, 26, 2008
} 


\section{INTRODUCTION}

The knowledge of simultaneous water and soil solutes transport is essential for researches involving environment and economic points of view, because it refers to both water use efficiency and chemical products application in agricultural production. Chemical substances, used in modern agriculture, are often distributed on soil surface, such as fertilizers, organic manure, insecticides, herbicides, and even agro-industrial residues. These inputs, when applied above the soil support capacity, may release ions and toxicant compounds, which can contaminate soil and underground waters. When available to soil solution, ions can be adsorbed by medium, absorbed by plants or lixiviated towards soil undersurface layers, causing damages to environment, through the uncontrolled application of these chemical substances (COSTA et. al., 1999).

Nitrate, as an anion, exhibits a great mobility and lixiviating potential in soils with high clay contents (negative charges), so causing serious problems of underground water contamination. According to EDWARDS et al. (1972), some ions, when available to soil solution, are quickly displaced inside the profile, as it happens with nitrogen, under the form of nitrate ions, which is strongly soluble in water and exhibits a great soil mobility. EXNER et al. (1991) verified a deep nitrate movement, at different application rates, under irrigation condition, whose results demonstrated that $95 \%$ of applied nitrate were lixiviated beneath culture radicular zone, and average pulse nitrate concentrations varied from 34 to $70 \mathrm{mg} \mathrm{L}^{-1}$ of nitrate.

The importance of a potassium inquiry is a function of its economical expressiveness, because it is present in the fertirrigation of the majority of cultures, and the knowledge of its soil displacement becomes important, mainly for the evaluation of this chemical component availability to plants inside radicular zone.

Potassium, according to MALAVOLTA (1980), is a macronutrient absorbed by soil solution through roots, with the predominance of diffusion process contact. In Brazil, culture potassium application is almost totally done in planting and/or covering with direct application to soil.

Sometimes application is complemented with foliar manuring (ZANINI, 1991).

When dealing with the simultaneous movement of soil water and solute, it is taken into consideration solute transport is a consequence of convection, i.e. of mass flow (laminar or viscous movement of soil) and diffusion (solute thermal movement inside of solution). These two transport process components, which occur at the same time, are essential for the establishment of handling practices to control soil ions (BRESLER, 1981). Solute dynamics inquiries not only offer a means for soil flow determination, but also give a physical explanation of phenomena occurring during ions percolation, exchange and adsorption, for mineral fertilizers and other salts (NIELSEN \& BIGGAR, 1961).

So, interactions between porous medium and percolating fluid properties are determined by solute transport parameters, under the influence of some factors acting on migration and chemical substances retention process, being prominent: kind of soil, mineralogy, cations exchange capacity, kind of cations adsorbed, percolation velocity, organic material contents, contaminant concentration, presence of other substances in percolating solution, hydro-geologic conditions, and medium temperature and $\mathrm{pH}$ (COSTA, 2002).

Therefore, the solution temperature effect upon potassium and nitrate ions parameters was inquired, through a compound solution application, under potassium and nitrate concentrations, getting effluent distribution curves, for a Red-Yellow Latossolo with average texture, classified in accordance with the Soil Classification Brazilian System (EMBRAPA, 1999). Through the numerical adjustment of equations against experimental values observed, respective solute transport parameters were obtained, for future applications on computational models. 


\section{MATERIAL AND METHODS}

Experiment was carried out under laboratory conditions, at the Department of Exact Sciences - ESALQ/USP. Soil material used came from a profile collected at the depth of $20 \mathrm{~cm}$, classified in accordance with the Soil Classification Brazilian System (EMBRAPA, 1999), as a Red-Yellow Latosol with average texture, having physical-hydric characteristics as follows: $70.6 \%$ sand, $11.52 \%$ silt, $17.78 \%$ clay, global density $=1.46 \mathrm{~g} \mathrm{~cm}^{-3}$, particle density $=2.57 \mathrm{~g} \mathrm{~cm}^{-3}$, porosity $=43 \%$ and saturated soil hydraulic conductivity $=7.25 \mathrm{~cm} \mathrm{~h}^{-1}$.

\section{Experiment installation in laboratory}

PVC columns were used, filled with soil material, with $20 \mathrm{~cm}$ height and $7.2 \mathrm{~cm}$ diameter, with nitrate and potassium solution going through them. Referred to solution temperature variation for different values treatments (ambient at 25 up to $28{ }^{\circ} \mathrm{C}, 40{ }^{\circ} \mathrm{C}$ e $50{ }^{\circ} \mathrm{C}$ ), procedure chosen was the passage of solution through bain-marie with circulation and temperature adjusting, by means of a calorimeter. Moreover, the temperature of solution entering soil column was constantly monitored by a thermometer, at different test temperatures applied. For helping at this stage, an electrical resistance for distilled water was prepared (Figures 1A and 1B).

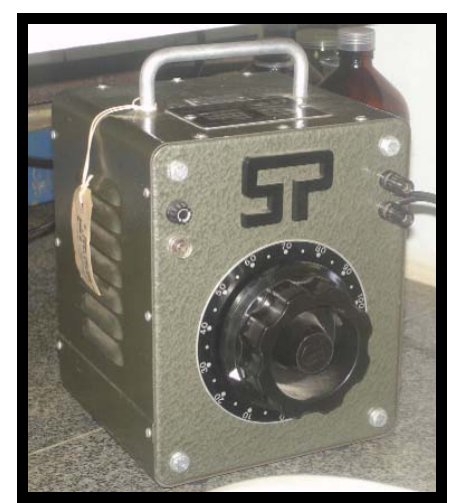

(A)

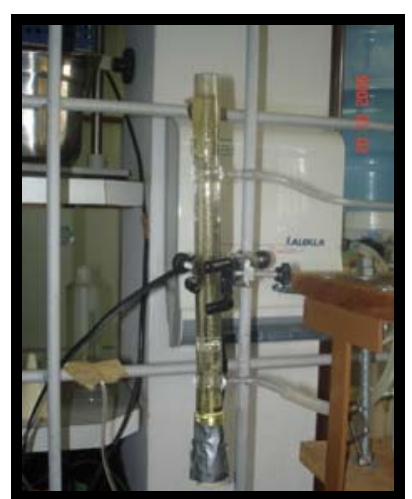

(B)

FIGURE 1. Varivolt equipment used for voltage adjustment to reach distilled water temperature (A) and electrical resistance installed to maintain distilled water temperature steady (B).

\section{Column preparation}

PVC column used for effluent collection presented volume of $814.30 \mathrm{~cm}^{3}$, totalling nine columns, divided in three treatments: ambient temperature $\left(25\right.$ up to $\left.28{ }^{\circ} \mathrm{C}\right)$, temperature of $40{ }^{\circ} \mathrm{C}$ and temperature of $50^{\circ} \mathrm{C}$, with three retrials for every treatment. In the lower part of column, a synthetic circular blanket was placed on a fabric and fastened by means of a threaded cap. To maintain a $1 \mathrm{~cm}$ steady blade, on the higher part of column, an experimental circuit was installed in laboratory, with a drainage installation removing all excess.

For test starting it was necessary at first to saturate column with distilled water, performing process slowly with column placed inside of a vessel, and water was added through dropping, up to the height of about $2 / 3$ of column. Afterwards, assembly kept still during 24 hours to complete saturation, and after this period, test was initiated, leaving then distilled water to pass at ambient temperature through soil column (also during about 24 hours), allowing all solute quantity occasionally present in soil solution to be removed. Due to the period of 24 hours, an electrical resistance was used, to heat distilled water, with the only purpose of ending this process of lixiviation, so as to reach a steady thermal equilibrium of solution crossing through column. Moreover, column was coated with insulating material (polystyrene), in order to keep constant solution temperature, during the process of crossing through soil column.

Reaching a steady flow density, and at a respective constant temperature of corresponding treatments (ambient at 25 to $28^{\circ} \mathrm{C}, 40^{\circ} \mathrm{C}$ and $50{ }^{\circ} \mathrm{C}$ ), the change of water, also heated by solution at different temperature values, was carried out, controlled by means of a calorimeter and constantly 
monitored through a thermometer. Manual collection by means of collector flasks of solution volumes crossing through soil column, represented, individually, $15 \mathrm{~mL}$ of collected effluent. This volume was defined in function of pore volume (PV) (related to soil porosity, generally about 50\%) and of the quantity necessary to perform the analysis of previously reported chemical components.

\section{Chemical solutions used and effluents chemical analysis}

Chemical solutions of potassium and nitrate were used, by means of a compound solution preparation containing $0.326 \mathrm{~g}$ of potassium nitrate $\left(\mathrm{KNO}_{3}\right)$, together with $15.003 \mathrm{~g}$ of potassium chlorate $(\mathrm{KCl})$ diluted in $4 \mathrm{~L}$ of distilled water, resulting in a concentration of $50 \mathrm{ppm}$ of nitrate $\left(\mathrm{NO}_{3}{ }^{-}\right)$and of $2.000 \mathrm{ppm}$ of Potassium $\left(\mathrm{K}^{+}\right)$.

Curve behavior was monitored by a quick test equipment (Horiba), showing test end when the initial concentration value of $2.000 \mathrm{ppm}$ for potassium $\left(\mathrm{K}^{+}\right)$and of $50 \mathrm{ppm}$ for nitrate $\left(\mathrm{NO}_{3}\right)$ was reached, by means of the compound solution of potassium nitrate $\left(\mathrm{KNO}_{3}\right)$ with potassium chlorate $(\mathrm{KCl})$, in the effluent. Samples were submitted to laboratory analyses. Effluents chemical determinations were performed using a flame photometer and FIA - Flow Injection Analysis, for potassium and nitrate respectively.

The computational software "DISP" was used, to make the fit of effluent distribution curves (BORGES JÚNIOR \& FERREIRA, 2002), developed in Delphi 3 software language, using least squares method to obtain parameter estimations $\mathrm{P}$ (column number or Peclet number) and retardation factor $(\mathrm{R})$, whose entry parameters are: number of observations (observed values of relative concentrations $(\mathrm{Ce})$, as a function of the number of pore volume; total porosity (decimal); flow density $\left(\mathrm{cm} \mathrm{h}^{-1}\right)$, and soil column length $(\mathrm{cm})$. Software output data are: estimated values of relative concentrations $(\mathrm{Ce})$, as a function of the pore volume; graphical representation between relative concentration and pore volume (observed and estimated); parameters estimators $\mathrm{P}, \mathrm{R}$ and $\mathrm{D}$; residues square addition (Rs), and determination coefficient $\left(\mathrm{R}^{2}\right)$.

\section{RESULTS AND DISCUSSION}

\section{Nitrate and potassium ions displacement at ambient temperature $\left(25\right.$ to $\left.28^{\circ} \mathrm{C}\right)$}

For ions displacement at ambient temperature of potassium ion, a greater displacement to right of effluents distribution, showing a greater adsorption by soil, when referred to nitrate ion, was observed. Other fact observed was that, to reach final concentration after the passage of potassium nitrate and potassium chlorate through soil column, one could remark the need, for potassium ion, of a minimum quantity of three pore volume and a maximum of four pore volume, against nitrate ion, which remained about $2 \mathrm{PV}$, not overcoming $2.5 \mathrm{PV}$ during every retrial.

It was remarked, in average terms, nitrate and potassium retardation factor (R) was respectively 1.2 and 1.8 , what corroborates the previous comment potassium ion exhibited a greater adsorption referred to nitrate ion. Therefore, even though dealing with sandy soil, the element influenced ions displacement was companion ion, because potassium, even though being a cation, comes together with an anion (chlorine), what collaborated to the effect of adsorption to soil. Instead, nitrate comes together with potassium ion (potassium nitrate), what caused greater dragging, due to the greater potassium atomic mass, referred to chlorate ion, so exhibiting a greater solution displacement, as verified by FERREIRA et al. (2005) (Figure 2). 


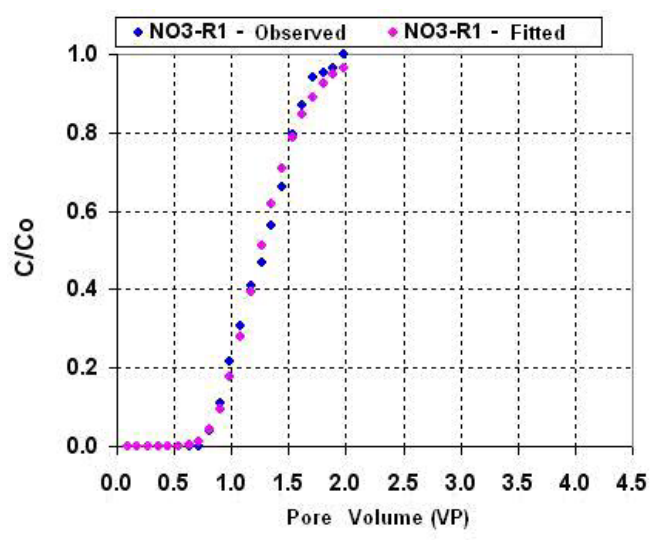

(A)

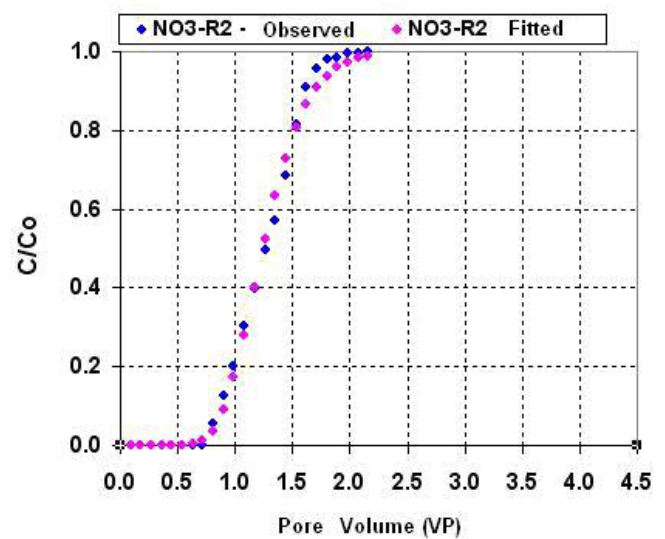

(B)

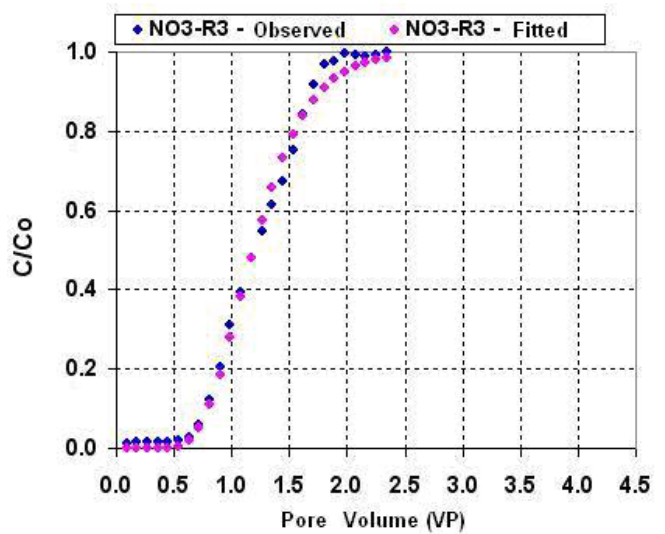

(C)

FIGURE 2. Breakthrough curves, obtained with solution at ambient temperature, with three repetitions, for nitrate (A, B and $\mathrm{C})$ and potassium nitrate $(\mathrm{D}, \mathrm{E}$ and $\mathrm{F})$.

\section{Displacement of nitrate and potassium ions at $40{ }^{\circ} \mathrm{C}$ temperature}

For the evaluation of both ions displacement at the solution temperature of $40{ }^{\circ} \mathrm{C}$, for potassium ion a greater displacement of effluent distribution curves to the right side of " $\mathrm{x}$ " axis was observed, showing again potassium ions were retained by soil with greater intensity, when referred to nitrate ions.

Referred to the pores quantity required to reach final concentration for potassium ion, a minimum quantity of $2.5 \mathrm{PV}$ and a maximum quantity about $2 \mathrm{PV}$ were observed. The same fact had been observed in the case of ambient temperature.

However, it was observed potassium ion, at the temperature of $40{ }^{\circ} \mathrm{C}$, when coming out during effluents collection by means of collector flasks, started exhibiting values below 1 PV, i.e. higher velocity of effluent coming out, referred to ambient temperature, reaching its end, i.e., 
solution coming out equal to entry solution (100\%), about $3 \mathrm{PV}$ up to $3.5 \mathrm{PV}$, with a minimum of 2.5 PV for retrial 2. This fact indicates a temperature effect when referred to solution viscosity, causing an increase of solution displacement through soil column.

As for nitrate ion, below $40{ }^{\circ} \mathrm{C}$ temperature a time reduction in outcome, when referred to ambient temperature, was also observed, exhibiting values of about $0.5 \mathrm{PV}$, when, before, at ambient temperature conditions, it was of about $0.75 \mathrm{PV}$. For potassium ion, outcome time at the temperature of $40{ }^{\circ} \mathrm{C}$ remained about $0.8 \mathrm{PV}$, i.e., less than the correspondent at ambient temperature (1.0 PV).

In average terms, it was observed nitrate and potassium ions retardation factor $(\mathrm{R})$ was 1.02 and 1.47 respectively, confirming previous comment and showing temperature effect for ions displacement, when referred to ambient temperature (Figure 3).

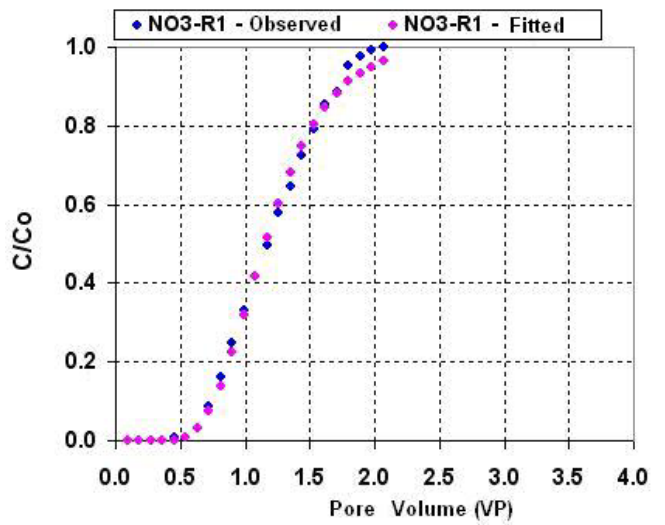

(A)

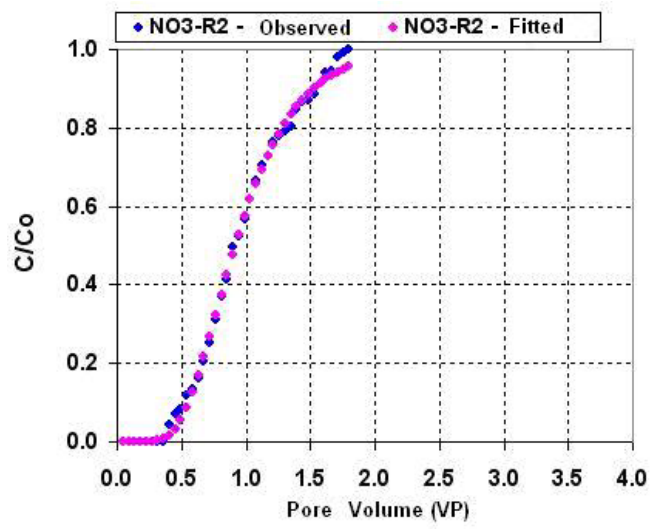

(B)

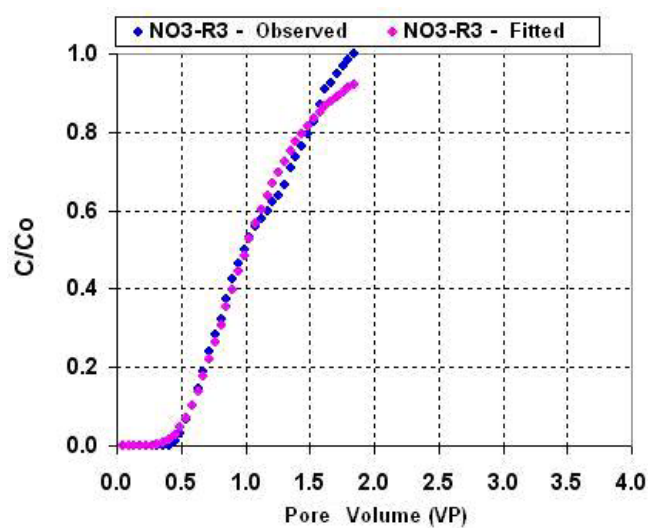

(C)

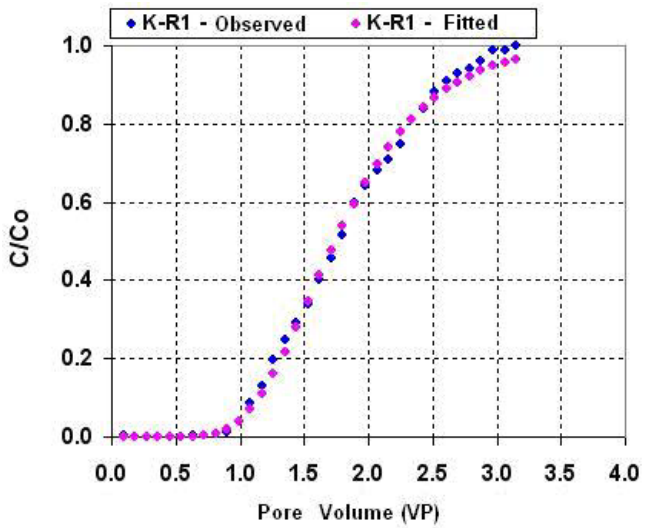

(D)

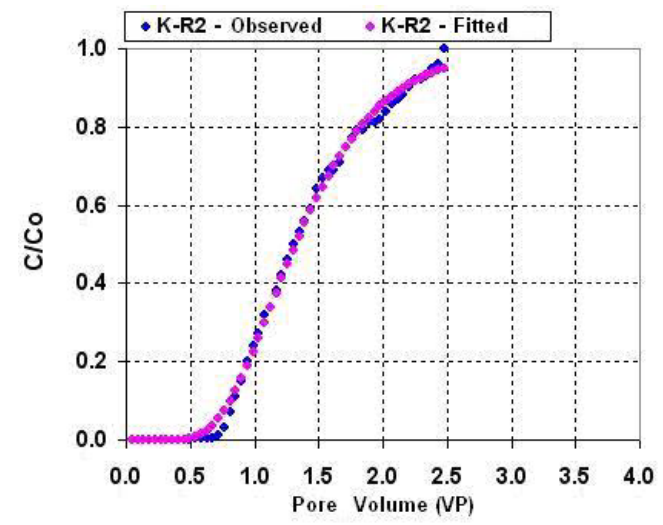

(E)

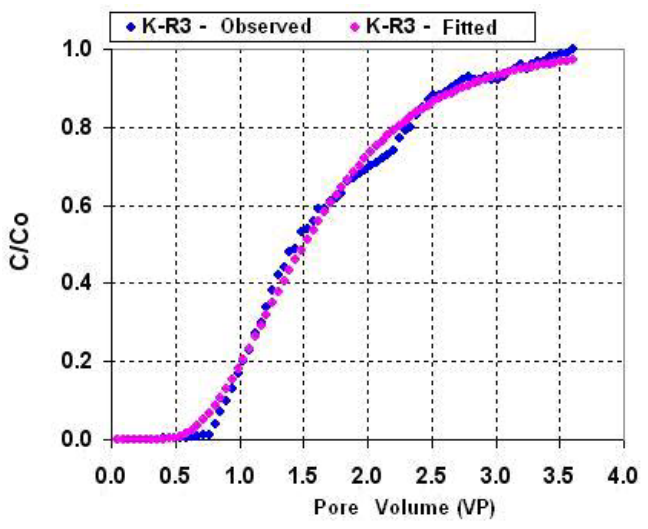

(F)

FIGURE 3. Breakthrough curves obtained with solution at the temperature of $40{ }^{\circ} \mathrm{C}$, with three repetitions, for nitrate ions (A, B and $C)$ and potassium (D, E and F). 


\section{Nitrate and potassium ions displacement at the temperature of $50{ }^{\circ} \mathrm{C}$}

When evaluating nitrate and potassium displacement at the temperature conditions of $50{ }^{\circ} \mathrm{C}$, the same trend of a greater effect of potassium ion adsorption referred to nitrate was observed again (Figure 4).

It was observed potassium ion, at $50^{\circ} \mathrm{C}$, started exhibiting, when collecting effluents in collector flasks, slightly greater outcome values than those obtained at the temperature of $40{ }^{\circ} \mathrm{C}$, reaching its end, i.e., outcome solution equal to entry solution $(100 \%)$, with about 3.0 PV. With nitrate ion, at the temperature value of $50{ }^{\circ} \mathrm{C}$, an outcome time reduction, when referred to ambient temperature, was also observed, however, with values near to those obtained at the temperature of $40{ }^{\circ} \mathrm{C}$ (about 0.5 PV), whereas, before, at ambient temperature conditions, it was of about $0.75 \mathrm{PV}$.

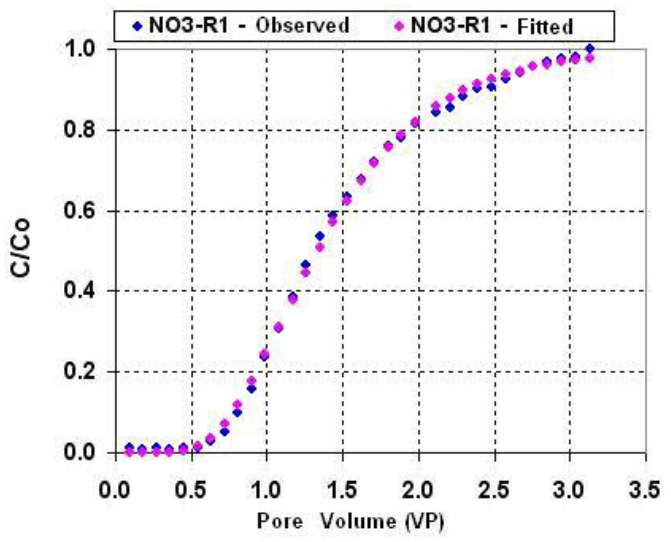

(A)

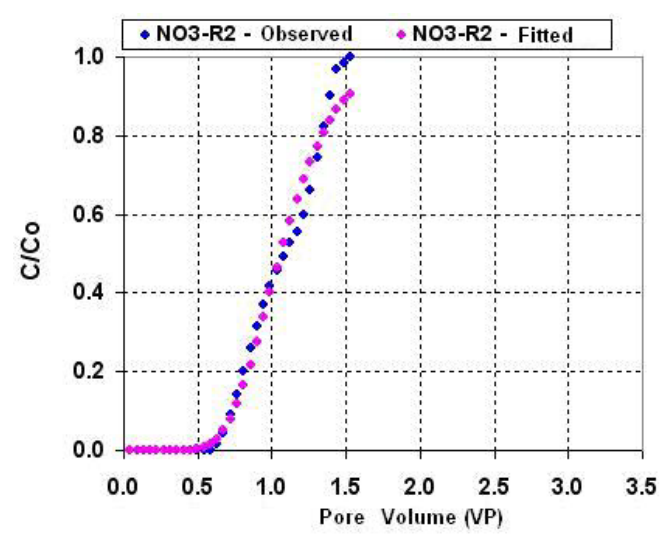

(B)

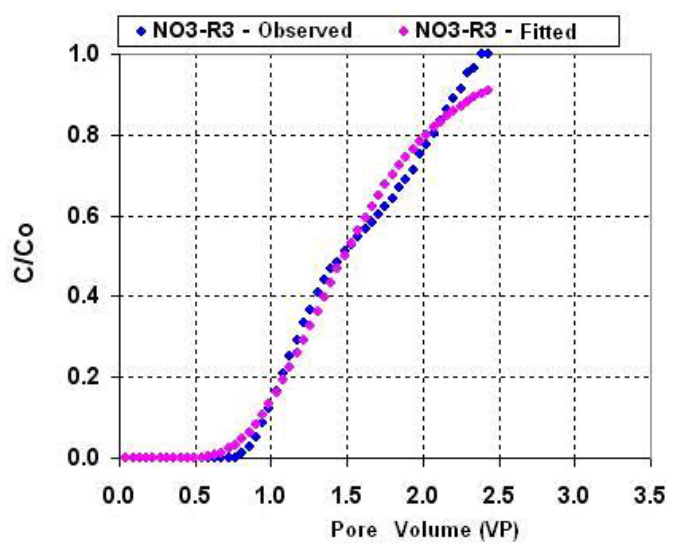

(C)

FIGURA 4. Breakthrough curves obtained with solution at the temperature of $50{ }^{\circ} \mathrm{C}$, with three retrials, for nitrate ions (A, B and C) and potassium (D, E and F).

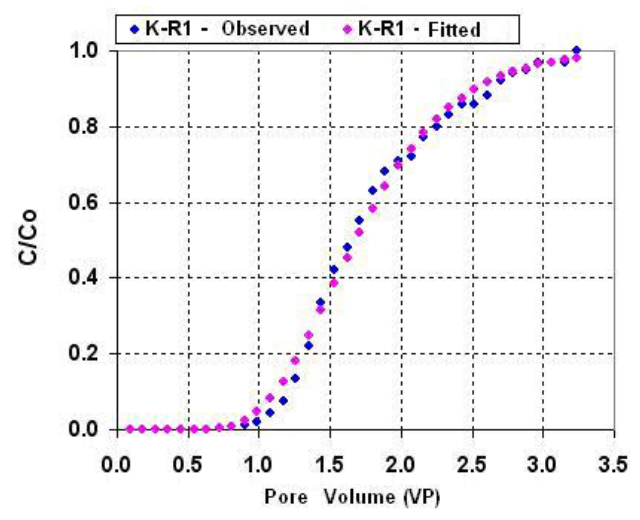

(D)

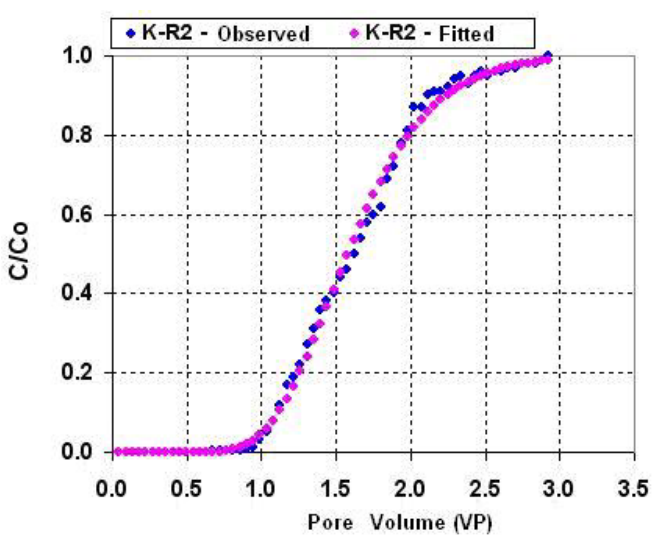

(E)

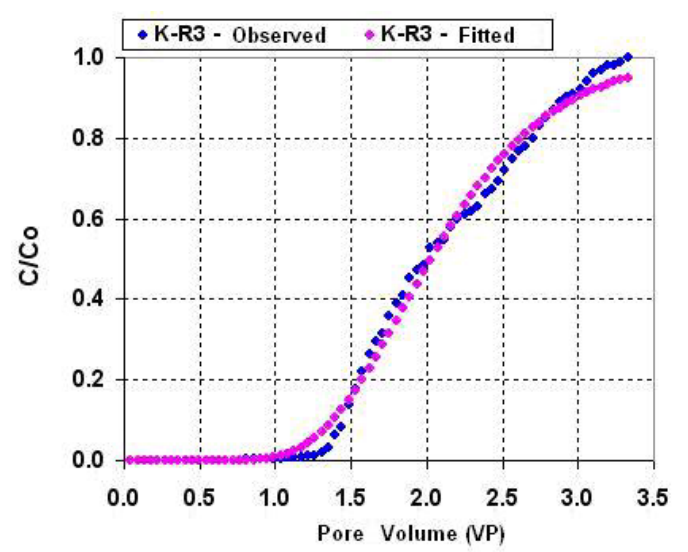

(F) 
With the values of relative concentration equal to $50 \%$, it was observed, in average terms, lack factor values $(\mathrm{R})$ for nitrate and potassium ions were 1.35 and 1.66 respectively, showing the temperature effect on ions displacement, referred to ambient temperature, as well as companion ions effects. It was noted that, with regard to values obtained at the temperature of $40{ }^{\circ} \mathrm{C}$, little differences existed, possibly due to the $10{ }^{\circ} \mathrm{C}$ increase. Therefore, even though potassium ion exhibited again a greater adsorption effect, when compared to nitrate ion, mainly referred to ambient temperature, it is clear that, to demonstrate with greater significance the temperature effect, it would be necessary a greater temperature increase, referred to $40{ }^{\circ} \mathrm{C}$ (Figure 4).

Generally speaking, breakthrough curves showed the trend moving to left, as long as solution temperature was increased. Effluent distribution curves which moved to left, exhibited lower retardation factor values. RAO et al. (1980) suggest that, the greater is the effluent curve displacement to right, the greater is also colloids surface adsorption, which is related to ion adsorption energy.

Adsorption effect was easily observed through effluent distribution curves, becoming more self-evident for potassium ion, than for nitrate ion. That explains the obtaining of greater values of retardation factor for potassium and the greater displacement of effluent distribution curve to right for potassium ion, referred to nitrate ion, at three temperatures. Similar results were obtained by MIRANDA et al. (2005), at ambient temperature.

\section{Transport parameters of nitrate and potassium ions at ambient temperature of 40 and $50{ }^{\circ} \mathrm{C}$}

For nitrate ion, related to retardation factor parameter, a reduction of values was observed, as long as ambient temperature was increased up to $40{ }^{\circ} \mathrm{C}$. This occurrence did not happen again between temperatures of 40 and $50{ }^{\circ} \mathrm{C}$, due to the increase of $10{ }^{\circ} \mathrm{C}$, any way demonstrating, however, a greater value of the dispersive effect caused by temperature increase.

With regard to dispersion factor (D), for nitrate ion, an increase of values in function of temperature rise occurred, as well as of pore water velocity, both as in function of Peclet number, as also in function of flow density. This demonstrates temperature effect on solution viscosity, reducing its values and making easy its displacement. Dispersivity did not exhibit any correlation with temperature rise (Table 1).

TABLE 1. Parameters for nitrate ion transport: retardation factor (R), dispersion coefficient (D), Peclet number $(\mathrm{P})$, pore water velocity as a function of flow density $(\mathrm{v}(\mathrm{q}))$, dispersivity as a function of Peclet number $(\lambda(\mathrm{P}))$ and dispersivity as a function of flow density $(\lambda(q))$ for the three replications of soil submitted to simulation.

\begin{tabular}{|c|c|c|c|c|c|c|c|}
\hline \multirow{3}{*}{ Replications } & \multicolumn{7}{|c|}{ Nitrate Transport Parameters } \\
\hline & $\mathrm{R}$ & $\begin{array}{c}\mathrm{D} \\
\left(\mathrm{cm}^{2} \min ^{-1}\right)\end{array}$ & $\mathrm{P}$ & 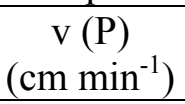 & $\begin{array}{c}\mathrm{v}(\mathrm{q}) \\
\left(\mathrm{cm} \mathrm{min}^{-1}\right)\end{array}$ & $\lambda(\mathrm{P})$ & $\lambda(q)$ \\
\hline & \multicolumn{7}{|c|}{ Ambient Temperature } \\
\hline 1 & 1.292 & 9.58 & 30.62 & 14.66 & 15.44 & 0.6535 & 0.6205 \\
\hline 2 & 1.279 & 7.46 & 33.96 & 12.66 & 13.29 & 0.5893 & 0.5613 \\
\hline 3 & 1.247 & 19.62 & 19.91 & 19.53 & 19.53 & 1.0047 & 1.0047 \\
\hline Average & 1.273 & 12.221 & 28.16 & 15.61 & 16.08 & 0.7491 & 0.7600 \\
\hline Replications & \multicolumn{7}{|c|}{$40{ }^{\circ} \mathrm{C}$ Temperature } \\
\hline 1 & 1.219 & 21.045 & 17.93 & 18.86 & 18.87 & 1.1159 & 1.1153 \\
\hline 2 & 0.995 & 44.334 & 12.12 & 26.86 & 26.86 & 1.6506 & 1.6506 \\
\hline 3 & 1.103 & 33.827 & 10.13 & 17.13 & 17.14 & 1.9747 & 1.9736 \\
\hline Average & 1.106 & 33.069 & 13.39 & 20.95 & 20.95 & 1.5804 & 1.5785 \\
\hline Replications & \multicolumn{7}{|c|}{$50{ }^{\circ} \mathrm{C}$ Temperature } \\
\hline 1 & 1.465 & 33.017 & 10.19 & 16.82 & 16.82 & 1.9630 & 1.9630 \\
\hline 2 & 1.102 & 29.507 & 25.41 & 37.48 & 37.48 & 0.7873 & 0.7873 \\
\hline 3 & 1.587 & 66.277 & 14.25 & 47.22 & 47.22 & 1.4036 & 1.4036 \\
\hline Average & 1.385 & 42.934 & 16.61 & 33.84 & 33.84 & 1.3846 & 1.2687 \\
\hline
\end{tabular}


Referring to transport parameters obtained for potassium ion, it was possible to observe all values were higher, at every temperature, related to nitrate. For dispersion coefficient, an increase of $42.75 \%$ was observed, at the temperature of $40{ }^{\circ} \mathrm{C}$, referred to ambient temperature. Pore water velocity, both in function of Peclet number as flow density (q), exhibited increase as long as temperature was risen, what is directly tied to a solution viscosity reduction. As for dispersivity, it was observed that its value increased averagely, both as a function of Peclet number, as flow density, about $88 \%$, when varying from ambient temperature to the temperature of $40{ }^{\circ} \mathrm{C}$ (Table 2 ).

Solute mobility on soil is inversely related to its adsorption to solid fraction, or to medium conditions, which promote ions precipitation (MATOS et al., 1998). Retardation factor (R) is also called partition coefficient, because it represents the ratio between solutes concentration in solid and liquid phases (MIRANDA, 2001). For every temperature, potassium exhibited greater retardation factor values than nitrate, showing a greater interaction with soil solid fraction.

TABLE 2. Potassium ion transport parameters: retardation factor (R), dispersion coefficient (D), Peclet number $(\mathrm{P})$, pore water velocity as a function of Peclet number $(\mathrm{v}(\mathrm{P}))$, pore water velocity as a function of flow density (v(q)), dispersivity as a function of flow density $(\lambda(q))$ for the three Replications of soil submitted to simulation.

\begin{tabular}{|c|c|c|c|c|c|c|c|}
\hline \multirow{3}{*}{ Replications } & \multicolumn{7}{|c|}{ Potassium Transport Parameters } \\
\hline & $\mathrm{R}$ & $\begin{array}{c}\mathrm{D} \\
\left(\mathrm{cm}^{2} \min ^{-1}\right)\end{array}$ & $\mathrm{P}$ & 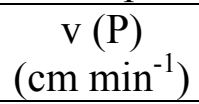 & $\begin{array}{c}\mathrm{v}(\mathrm{q}) \\
\left.(\mathrm{cm} \mathrm{min})^{-1}\right)\end{array}$ & $\lambda(\mathrm{P})$ & $\lambda(q)$ \\
\hline & \multicolumn{7}{|c|}{ Ambient Temperature } \\
\hline 1 & 1.940 & 8.485 & 30.38 & 12.88 & 15.83 & 0.6588 & 0.5360 \\
\hline 2 & 1.930 & 13.226 & 22.85 & 15.11 & 13.56 & 0.8753 & 0.9754 \\
\hline 3 & 1.952 & 21.586 & 18.51 & 19.97 & 19.98 & 1.0809 & 1.0804 \\
\hline Average & 1.941 & 14.432 & 23.91 & 15.98 & 16.45 & 0.8717 & 0.8773 \\
\hline Replications & \multicolumn{7}{|c|}{$40{ }^{\circ} \mathrm{C}$ Temperature } \\
\hline 1 & 1.842 & 22.072 & 17.72 & 19.55 & 19.56 & 1.1290 & 1.1284 \\
\hline 2 & 1.424 & 42.069 & 12.91 & 27.15 & 27.15 & 1.5495 & 1.5495 \\
\hline 3 & 1.681 & 40.963 & $8.6 ?$ & 17.77 & 17.77 & 2.3052 & 2.3052 \\
\hline Average & 1.649 & 35.035 & 13.10 & 21.49 & 21.49 & 1.6612 & 1.6303 \\
\hline Replications & \multicolumn{7}{|c|}{$50^{\circ} \mathrm{C}$ Temperature } \\
\hline 1 & 1.769 & 17.858 & 18.94 & 16.91 & 16.91 & 1.0561 & 1.0561 \\
\hline 2 & 1.641 & 29.794 & 26.15 & 38.95 & 38.96 & 0.7649 & 0.7647 \\
\hline 3 & 2.125 & 44.991 & 21.14 & 47.55 & 47.57 & 0.9462 & 0.9458 \\
\hline Average & 1.845 & 30.881 & 22.07 & 34.47 & 34.48 & 0.9224 & 0.8956 \\
\hline
\end{tabular}

Referred to dispersion coefficient, OLIVEIRA et al. (2004) stated, a lower adsorbed/ adsorbing interaction leads to a greater uniformity of solute displacement, according to the displacer fluid which exhibits the greatest concentration. Results obtained are in accordance with this statement, when applied to nitrate ion, as temperature rise caused a greater ion interaction with the soil, reducing its concentration in the displacer fluid, and a dispersion increase, only for nitrate ion; for potassium ion, with temperature variation from $40{ }^{\circ} \mathrm{C}$ to $50{ }^{\circ} \mathrm{C}$, dispersion coefficient decreases.

\section{CONCLUSIONS}

Temperature exhibited a great influence on the velocity of solution displacement through porous medium and also on dispersion coefficient.

Temperature variation exhibited influence on values of lack factor parameter, when an increase of ambient temperature to the temperature of $40{ }^{\circ} \mathrm{C}$ occurred.

Potassium ion exhibited a greater interaction with the solid fraction of soil, when referred to nitrate ion. 


\section{REFERENCES}

BORGES JÚNIOR, J.C.F.; FERREIRA, P.A. Programa computacional para cálculo de parâmetros do transporte de solutos em deslocamento de fluídos miscíveis. In: CONGRESSO BRASILEIRO DE ENGENHARIA AGRÍCOLA, 31., 2002, Salvador. Anais... Jaboticabal: Sociedade Brasileira de Engenharia Agrícola, 2002. 1 CD-ROM.

BRESLER, E. Convective and pore scale dispersive solute transport in unsaturated heterogeneous fields. Water Resources Research, Washington, v.37, n.6, p.1.683-93, 1981.

COSTA, S.N.; MARTINEZ, M.A.; MATOS, A.T.; RAMOS, V.B.N. Mobilidade de nitrato em colunas de solo sob condições de escoamento não permanente. Revista Brasileira de Engenharia Agrícola e Ambiental, Campina Grande, v.3, n.2, p.190-4, 1999.

COSTA, P.O. da S. Avaliação em laboratório, do transporte de contaminantes no solo do aterro sanitário de Sauípe-BA. 2002. 171 f. Dissertação (Mestrado em Engenharia Civil) - Pontifícia Universidade Católica do Rio de Janeiro, Rio de Janeiro, 2002.

EDWARDS, D.M.; FISCHBACH, P.E.; YOUNG, L.L. Movement of nitrate under irrigated agriculture. Transactions of the ASAE, St. Joseph, v.15, n.1, p.73-5, 1972.

EMBRAPA. EMPRESA BRASILEIRA DE PESQUISA AGROPECUÁRIA. Sistema brasileiro de classificação de solos. Brasília, 1999. 412 p.

EXNER, M.E.; BURBACH, M.E.; WATTS, D.G.; SHEARMAN, R.C.; SPALDIND, R.F. Deep nitrate movement in the unsaturated zone of simulated urban lawn. Journal Environmental Quality, Madison, v.20, n.1, p.658-62, 1991.

FERREIRA, G.M.; MIRANDA, J.H.; SABADIN, J.F.G.; ROSSI, P.; DUARTE, S.N. Avaliação da influência dos íons cloreto e nitrato no deslocamento do íon potássio no solo. In: CONGRESSO BRASILEIRO DE ENGENHARIA AGRÍCOLA, 34., 2005, Canoas. Anais... Jaboticabal: Associação Brasileira de Engenharia Agrícola, 2005. 1 CD-ROM.

MALAVOLTA, E. Potássio, magnésio e enxofre nos solos e culturas brasileiras. 2.ed. Piracicaba: Instituto Internacional de Pesquisa da Potassa, 1980. 91 p. (Boletim Técnico, 4)

MATOS, A.T.; COSTA, L.M. da; FONTES, M.P.F.; MARTINEZ, M.A. Correlação entre os fatores de retardamento e coeficientes de dispersão-difusão do zinco, cádmio, cobre e chumbo, e algumas propriedades físicas dos solos. Engenharia na Agricultura, Viçosa, v.6, n.4, p.235-46, 1998.

MIRANDA, J.H. Modelo para simulação da dinâmica de nitrato em colunas verticais de solo não saturado. 2001.79 f. Tese (Doutorado em Irrigação e Drenagem) - Escola Superior de Agricultura "Luiz de Queiroz", Universidade de São Paulo, Piracicaba, 2001.

MIRANDA, J.H.; DUARTE, S.N.; LIBARDI, P.L.; FOLEGATTI, M.V. Simulação do deslocamento de potássio em colunas verticais de solo não-saturado. Engenharia Agrícola, Jaboticabal, v.25, n.3, p.677-85, 2005.

NIELSEN, D.R.; BIGGAR, J.W. Miscible displacement in soils: I. Experimental Information. Soil Science Society of America, Madison, v.25, n.1, p.1-5, 1961.

OLIVEIRA, E.M.M.; RUIZ, H.A.; FERREIRA, P.A.; ALVAREZ V.V.H.; BORGES JÚNIOR, J.C.F. Fatores de retardamento e coeficientes de dispersão/difusão de fosfato, potássio e amônio em solos de Minas Gerais. Revista Brasileira de Engenharia Agrícola e Ambiental, Campina Grande, v.8, n.2/3, p.196-203, 2004.

RAO, P.S.C.; ROLSTON, D.E.; JESSUP, R.E.; DAVIDSON, J.M. Solute transport in aggregated porous media: theoretical and experimental evaluation. Soil Science Society of American Journal, Madison, v.44, p.1.139-46, 1980.

ZANINI, J.R. Distribuição de água e do íon K+ no solo, aplicados por fertirrigação em gotejamento. II - Teores de K+ no bulbo molhado. ITEM - Irrigação e Tecnologia Moderna, Brasília, v.46, n.1, p.24-38, 1991. 